Smith, D. C., Bassham, J. A. \& Kirk, M. (1961). Biochim. biophys. Acta, 48, 299.

Smith, J. H. C. \& Benitez, A. (1955). In Modern Methods of Plant Analysis, vol. 4, p. 142. Ed. by Paech, K. \& Tracey, M. V. Berlin, Göttingen and Heidelberg: Springer-Verlag.

Smith, P. W. G. (1957). J. chem. Soc. p. 3985.

Spackman, D. H., Stein, W. H. \& Moore, S. (1958). Analyt. Chem. 30, 1190.

Synge, R. L. M. (1951). Biochem. J. 49, 642.

Synge, R. L. M. (1957). Biochem. J. 65, 266.

Synge, R. L. M. \& Wood, J. C. (1958). Biochem. J. 70, 321.

Synge, R. L. M. \& Youngson, M. A. (1961a). Biochem. J. $78,708$.
Synge, R. L. M. \& Youngson, M. A. (1961b). Biochem. J. 78, $31 P$.

Ts'o, P. O. P. \& Sato, C. S. (1959). J. biophys. biochem. Cytol. 5, 59.

Wallach, D. F. H., Soderberg, J. \& Bricker, L. (1960). Cancer Res. 20, 397.

Wallach, D. F. H., Surgenor, D. M. \& Steele, B. B. (1958). Blood, 13, 589.

Webster, G. R. \& Folch, J. (1961). Biochim. biophys. Acta, 49, 399.

Wren, J. J. (1960). Nature, Lond., 185, 295.

Zill, L. P. \& Harmon, E. A. (1961). Biochim. biophys. Acta, 53, 579.

Zill, L. P. \& Harmon, E. A. (1962). Biochim. biophys. Acta, $57,573$.

Biochem. J. (1964) 91, 120

\title{
Incorporation of $\left[1-{ }^{14} \mathrm{C}\right]$ Acetate into the Lipids of the Silkworm Bombyx mori L.
}

\author{
BY S. SRIDHARA AND J. V. BHAT \\ Fermentation Technology Laboratory, Indian Institute of Science, Bangalore 12, India
}

\author{
(Received 3 July 1963)
}

Unlike vertebrates, insects require a dietary source of sterol for their normal growth and development (Levinson, 1955; Lipke \& Fraenkel, 1956; Monroe, 1960). In mammals the biosynthesis of the sterol molecule from $\mathrm{C}_{2}$ units has been demonstrated by isotopic-tracer techniques (Cornforth, 1959). However, although there was incorporation of $\left[{ }^{14} \mathrm{C}\right]$ acetate into the lipid fractions of insects, none could be detected in the sterol fractions (Clark \& Bloch, 1959a,b, $c$; Robbins, Kaplanis, Louloudes \& Monroe, 1960; Louloudes, Kaplanis, Robbins \& Monroe, 1961). Saito, Yamazaki \& Kobayashi (1963) claimed the incorporation of $\left[2-{ }^{14} \mathrm{C}\right]$ acetate into the digitonide fraction of the silkworm at the prepupal and pupal stages. This led them to the conclusion that the brain takes part in the sterol metabolism of the silkworm. The observation by Kirimura, Saito \& Kobayashi (1962) that the brain hormone is cholesterol has not, however, been accepted by Ichikawa \& Ishizaki (1963). An investigation designed to follow the incorporation of $\left[1-{ }^{14} \mathrm{C}\right]$ acetate into the saponifiable and unsaponifiable fractions of the silkworm Bombyx mori was undertaken and the results recorded are presented below.

\section{EXPERIMENTAL}

Mature larvae that had been starved overnight were injected with 10 or $20 \mu$ l. of sodium [1-14 C]acetate solution containing $0.5 \mu \mathrm{c} / 10 \mu \mathrm{l}$. The sodium $\left[1^{-{ }^{14}} \mathrm{C}\right]$ acetate (sp. activity $12 \cdot 8 \mu \mathrm{c} / \mathrm{mg}$.) was obtained from A.E.E.T., India. The injection was made with an Agla micrometer syringe at the fourth or fifth segment, the loss of blood being minimized by placing a thin coat of collodion over the site. Five-day-old pupae were injected with $10 \mu \mathrm{l}$. of the solution. Other larvae were fed on mulberry leaves smeared uniformly with $3 \mu \mathrm{C}$ of the [1-14 $\mathrm{C}]$ acetate solution. [A piece of mulberry leaf $\left(4 \frac{1}{2} \mathrm{~cm} . \times 4 \mathrm{~cm}\right.$.) $2 \mathrm{hr}$. after being plucked was uniformly smeared with $3 \mu \mathrm{C}$ of $\left[1-{ }^{14} \mathrm{C}\right]$ acetate. It was folded inwards along the middle and fixed on to a split cork with a pin and used for feeding. This procedure was developed for quantitative nutritional experiments by Murthy (1953).] All the operations were carried out at room temperature $\left(24^{\circ}\right)$.

The larvae or pupae were anaesthetized with ether after $8 \mathrm{hr}$. and then processed at once. Larvae fed on $\left[1{ }^{14} \mathrm{C}\right]$ acetate were washed twice with distilled water to remove radioactive material adhering to the body surface before being anaesthetized. The unconsumed leaf was washed with water, combined with the earlier washings and examined for total residual activity, which was found to be less than $2 \%$ of the total administered dose.

Isolation procedures. For each analysis two larvae or pupae were cut into small pieces and homogenized in $95 \%$ $(\mathrm{v} / \mathrm{v})$ ethanol for a few minutes in a MSE homogenizer. The homogenate was extracted four times with 5 vol. of ethanol-diethyl ether $(3: 1, v / v)$ mixture and finally with light petroleum (b.p. $40-50^{\circ}$ ) overnight. The extracts were pooled and filtered, and the solvent was removed under suction. The fat residue was dissolved in light petroleum and washed twice with water and once with $50 \%(\mathrm{v} / \mathrm{v})$ ethanol. The light petroleum layer was dried over anhydrous sodium sulphate, and the lipid was recovered, weighed and its activity measured. 
The lipid was then saponified for $30 \mathrm{~min}$. in $80 \%(\mathrm{v} / \mathrm{v})$ ethanol containing $10 \%(\mathrm{w} / \mathrm{v})$ of pyrogallol $(1 \mathrm{ml} . / \mathrm{g}$. wet wt.) and $40 \%$ alkali (1 ml./g. wet wt.). The unsaponifiable material was extracted into light petroleum which was washed repeatedly with water and finally with $70 \%(v / v)$ ethanol. The total radioactivity of the unsaponifiable material was determined, and it was further fractionated by chromatography on an alumina column (Jayaraman \& Ramasarma, 1961). Fractions were eluted in $0 \%, 5 \%$, $10 \%$ and $20 \%(v / v)$ diethyl ether in light petroleum. For the particular batch of alumina used, the deactivation necessary for eluting ubiquinone (coenzyme Q), ubichromenol and sterol in 5\%, $10 \%$ and $20 \%(\mathrm{v} / \mathrm{v})$ diethyl ether in light petroleum respectively was $6.5 \%$. The loading factor was $5 \mathrm{mg}$. of unsaponifiable material/g. of alumina.

The washings were combined with the original water layer, and the whole was refluxed for a further period of $4 \mathrm{hr}$. and then acidified with $50 \% \mathrm{HCl}$, and the fatty acids were extracted into light petroleum and the total radioactivity was determined. The individual fatty acids in the mixture were determined according to the method of Viswanathan \& Meerabai (1961). The radioactivity in the individual acids was determined as follows: five spots of $25 \mu \mathrm{l}$. each, corresponding to the total application of $125 \mu \mathrm{l}$. of the solution, were run on a single chromatogram together with a standard mixture, with $90 \%(v / v)$ acetic acid as the solvent; the paper was dried in air and exposed to iodine vapour. After stained bands had been marked the iodine was allowed to evaporate and the bands were cut out and pooled. When the radioactivity of the saponifiable material was low, fatty acids were collected from two chromatograms (ten spots).

The pooled bands were extracted four times with light petroleum followed once by ether, which extracted all the fatty acid present together with the paraffin in the chromatogram. This was extracted by partition in light petroleum-ethanolic alkali. The recovery of the fatty acids obtained by this procedure was about $90 \%$.

Counting. All the radioactive measurements were performed with a thin-end-window Geiger-Müller tube on aluminium planchets for sufficient time to give a standard error of $\pm 5 \%$. The observed counting rates were corrected for self-absorption and background.

\section{RESULTS}

$\left[1-{ }^{14} \mathrm{C}\right]$ Acetate was utilized by the silkworm for the biosynthesis of lipid and its incorporation was much the same whether administered orally or parenterally. The extent to which its incorporation occurred in pupae was, however, only half that in the larvae. The amount of ${ }^{14} \mathrm{C}$ recovered in the saponifiable fraction was always more than double that recovered in the unsaponifiable fraction, and the activity in the unsaponifiable fraction of the fat obtained from injected larvae was considerably greater than that of fed larvae (Table 1).

The unsaponifiable material, on fractionation on alumina columns (Table 2), yielded $35-40 \%$ of the radioactivity in the hydrocarbon fraction (obtained with light petroleum) and only 1-2\% as sterols (in the fraction obtained with $20 \%$ ether in
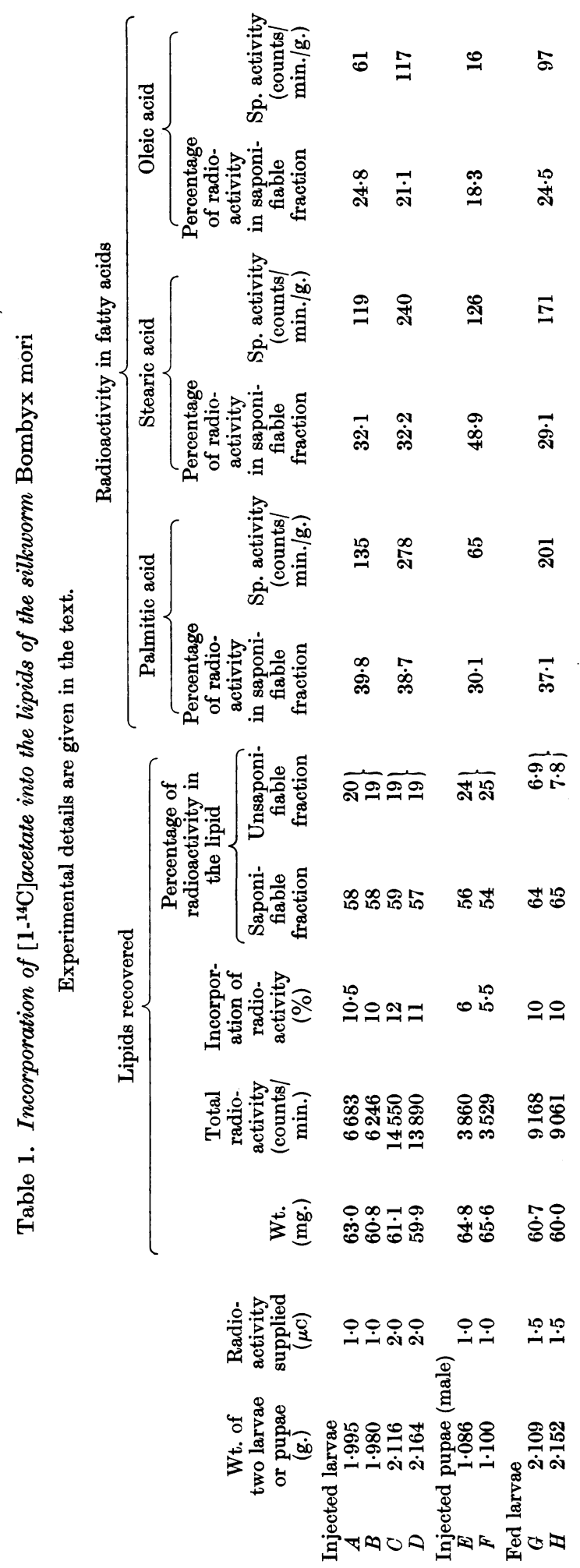
Table 2. Distribution of radioactivity of the total unsaponifiable material in various fractions collected from alumina columns

Experimental details are given in the text. Samples $A-H$ are the same as those referred to in Table 1 . The mean total recovery was $85 \%$.

Percentage of radioactivity of total unsaponifiable fraction

\begin{tabular}{|c|c|c|c|c|c|c|c|c|}
\hline \multirow[b]{2}{*}{ Eluent } & \multicolumn{4}{|c|}{ Injected larvae } & \multicolumn{2}{|c|}{ Injected pupae (male) } & \multicolumn{2}{|c|}{ Fed larvae } \\
\hline & $A$ & $B$ & $C$ & $D$ & $E$ & $F$ & $G$ & $H$ \\
\hline Light petroleum & $42 \cdot 5$ & $40 \cdot 9$ & $\mathbf{3 6} \cdot 3$ & $40 \cdot 1$ & $36 \cdot 1$ & $\mathbf{3 5 \cdot 5}$ & $44 \cdot 2$ & $45 \cdot 8$ \\
\hline $5 \%$ Ether in light petroleum & $22 \cdot 3$ & $24 \cdot 5$ & $23 \cdot 9$ & $22 \cdot 5$ & $35 \cdot 9$ & $35 \cdot 1$ & $19 \cdot 1$ & $18 \cdot 3$ \\
\hline $10 \%$ Ether in light petroleum & $18 \cdot 1$ & $16 \cdot 8$ & $18 \cdot 6$ & $19 \cdot 3$ & $8 \cdot 1$ & $9 \cdot 7$ & $18 \cdot 4$ & $17 \cdot 9$ \\
\hline $20 \%$ Ether in light petroleum & $1 \cdot 1$ & 1.0 & - & 0.4 & - & $0 \cdot 4$ & $1 \cdot 2$ & $1 \cdot 0$ \\
\hline Ether & $2 \cdot 1$ & 1.9 & $2 \cdot 4$ & $2 \cdot 1$ & $4 \cdot 9$ & $5 \cdot 0$ & $3 \cdot 5$ & $1 \cdot 8$ \\
\hline
\end{tabular}

Table 3. Incorporation of $\left[1{ }^{14} \mathrm{C}\right]$ acetate into the lipid of male and female pupae

Experimental details are given in the text.

\begin{tabular}{|c|c|c|c|c|c|c|}
\hline & \multirow{2}{*}{$\begin{array}{c}\text { Incorporation } \\
\text { of radioactivity } \\
(\%)\end{array}$} & \multicolumn{2}{|c|}{$\begin{array}{l}\text { Percentage of total } \\
\text { radioactivity in the lipid }\end{array}$} & \multicolumn{3}{|c|}{$\begin{array}{l}\text { Percentage of radioactivity in } \\
\text { the fatty acid mixture }\end{array}$} \\
\hline & & $\begin{array}{l}\text { Unsaponifiable } \\
\text { fraction }\end{array}$ & $\begin{array}{l}\text { Saponifiable } \\
\text { fraction }\end{array}$ & $\begin{array}{l}\text { Oleic } \\
\text { acid }\end{array}$ & $\begin{array}{l}\text { Stearic } \\
\text { acid }\end{array}$ & $\begin{array}{l}\text { Palmitic } \\
\text { acid }\end{array}$ \\
\hline $\begin{array}{r}\text { Male } \\
\quad(a) \\
(b)\end{array}$ & $\begin{array}{l}6 \cdot 4 \\
5 \cdot 6\end{array}$ & $\begin{array}{l}24 \cdot 7 \\
25 \cdot 8\end{array}$ & $\begin{array}{l}55 \cdot 2 \\
56 \cdot 3\end{array}$ & $\begin{array}{l}17 \cdot 9 \\
19 \cdot 1\end{array}$ & $\begin{array}{l}50 \cdot 0 \\
48.5\end{array}$ & $\begin{array}{l}31 \cdot 1 \\
30 \cdot 0\end{array}$ \\
\hline $\begin{array}{c}\text { Female } \\
\quad(a) \\
(b)\end{array}$ & $\begin{array}{l}4 \cdot 4 \\
4 \cdot 5\end{array}$ & $\begin{array}{l}25 \cdot 0 \\
25 \cdot 1\end{array}$ & $\begin{array}{l}59 \cdot 5 \\
54 \cdot 5\end{array}$ & $\begin{array}{l}18 \cdot 5 \\
18 \cdot 5\end{array}$ & $\begin{array}{l}48 \cdot 5 \\
50 \cdot 5\end{array}$ & $\begin{array}{l}30 \cdot 0 \\
30 \cdot 0\end{array}$ \\
\hline
\end{tabular}

light petroleum). The remaining radioactivity was recovered in the fractions obtained with $5 \%$ and $10 \%$ ether in light petroleum, which were expected to elute ubiquinone and ubichromenol respectively. The fraction obtained with $20 \%$ ether in light petroleum was treated with digitonin, and the sterol, after recovery into ether by treating the precipitate with pyridine, was assayed for its radioactivity. The sterol did not show any radioactivity, though the amount of sterol was very close to the theoretical value ( $1 \cdot 15 \%$ of fat) (unpublished work). No appreciable difference was observed between the ${ }^{14} \mathrm{C}$ recovered in the various fractions from fed larvae and the ${ }^{14} \mathrm{C}$ recovered in those from injected larvae, although there was considerable difference in the percentage incorporation of ${ }^{14} \mathrm{C}$ into the unsaponifiable material in the two series (Table 1). The fraction of the pupal-lipid unsaponifiable material obtained with $5 \%$ ether in light petroleum, as compared with that of larval lipid, always contained more ${ }^{14} \mathrm{C}$ than the fraction obtained with $10 \%$ ether in light petroleum. The elution pattern of the pooled fractions obtained with $5 \%$ and $10 \%$ ether in light petroleum showed only one peak in each fraction, and attempts to detect ubiquinone and ubichromenol in the respective fractions were unsuccessful.

The percentage radioactivity and the specific activity of individual fatty acids are shown in Table 1. The radioactivity in the oleic acid was obtained by deducting the radioactivity of palmitic acid from that of oleic acid and palmitic acid together. Most of the radioactivity was confined to palmitic acid, stearic acid and oleic acid, and the low radioactivity detected in linoleic acid and linolenic acid was lost on rechromatography.

The incorporation of ${ }^{14} \mathrm{C}$ into the total lipid and fractions in male and female silkworm pupae is shown in Table 3. Less incorporation was found in the females.

\section{DISCUSSION}

The recovery of ${ }^{14} \mathrm{C}$ in the silkworm lipid as a result of the injection or ingestion of $\left[1 .{ }^{14} \mathrm{C}\right]$ acetate was much higher than that observed in blowfly larvae and other insects, although the rates of incorporation cannot be strictly compared since the conditions of experiments vary from one another (Kodicek \& Levinson, 1960; Sedee, 1961). The rate of incorporation of ${ }^{14} \mathrm{C}$ in the larvae is almost twice that in the pupae, indicating the higher rate of metabolism in the larvae.

The amount of ${ }^{14} \mathrm{C}$ recovered in the unsaponifiable material of the silkworm lipid is 2-3 times that found in the blowfly, American cockroach or the housefly (Robbins et al. 1960; Louloudes et al. 1961; Sedee, 1961). The female of the housefly utilized [14 C]acetate 3.7-8 times more than the males for the synthesis of fatty acids, whereas the reverse was true with the cockroach (Robbins et al. 1960; Louloudes et al. 1961). No such differences were observed between the male and the female of the 
silkworm pupae. Differential synthesis could not be ascertained in the larvae owing to the difficulty of determining the sex at this stage.

The fact that only about $75 \%$ of the ${ }^{14} \mathrm{C}$ in the lipid was recoverable in the saponifiable and unsaponifiable fractions indicated that acetate was being utilized for the synthesis of the water-soluble moieties of the lipids. A similar observation was made in the synthesis of triglyceride glycerol by the blowfly larvae (Sedee, 1961). In the present instance, the high incorporation of ${ }^{14} \mathrm{C}$ into the unsaponifiable material in the injected silkworms, as compared with the orally fed silkworms, may possibly be explained by the longer duration of contact of the acetate with the metabolizing tissues in the former case.

The fractionation studies of the unsaponifiable material indicate the major component to be a hydrocarbon, an observation made previously for other insects (Clark \& Bloch, 1959a, b, $c$; Robbins et al. 1960). In the absence of radioactivity in the sterol fraction it is reasonable to conclude that the cholesterol biosynthetic pathway common to vertebrates is absent in the silkworm. This observation, when considered together with the proved essentiality of a sterol for the growth and development of the silkworm (Ito, 1960, 1961), tends to confer on cholesterol the role of a vitamin for the silkworm. The observation that the fractions obtained with $5 \%$ and $10 \%$ ether in light petroleum contained compound(s) that behaved as a single peak in each case may indicate the possibility that they were single compounds. The mere fact that the tests made to detect ubiquinone or ubichromenol failed cannot be taken as evidence against their possible biosynthesis.

Louloudes et al. (1961) observed the maximum incorporation of ${ }^{14} \mathrm{C}$ into oleic acid in the cockroach, and Sedee (1961) found the heaviest incorporation in the blowfly larvae to be into the unsaturated fatty acids. But in the silkworm the maximum incorporation of ${ }^{14} \mathrm{C}$ was always into the saturated fatty acids, as found in the cell-free systems of the fat body of Prodenia and Schistocerca migratoria (Zebe \& McShan, 1959; Teitz, 1961). However, most of the ${ }^{14} \mathrm{C}$ in the unsaturated fatty acids was localized in oleic acid, though its activity was always lower than those of palmitic acid and stearic acid. The complete lack of ${ }^{14} \mathrm{C}$ activity in linoleic acid and linolenic acid may mean the absence of a pathway for their synthesis from acetate. Generally speaking, these results closely resemble those recorded for man and other animals (Bernhard \& Schonheimer, 1940; Bernhard, 1947), and tend to support the view that the two acids have an essential role in nutrition of the silkworm even as it has been reported to be in the insect Ephestia (Fraenkel \& Blewett, 1946, 1947).

\section{SUMMARY}

1. Silkworm larvae and pupae have been shown to incorporate ${ }^{14} \mathrm{C}$ into the lipid at a high rate after the injection or ingestion of $\left[1-{ }^{14} \mathrm{C}\right]$ acetate.

2. The saponifiable fraction of the lipid recovered from the insect contained two or more times the radioactivity of the unsaponifiable fraction.

3. The sterol fraction did not contain any radioactivity.

4. Most of the radioactivity in the saponifiable fraction was present in palmitic acid, stearic acid and oleic acid, and the polyunsaturated acids were non-radioactive.

5. The amount of radioactivity incorporated was higher in the male than in the female pupae.

Thanks are due to Professor P.S. Sarma and Dr R. K. Maller for the use of counters, to Mr B. S. Baliga for help in counting, and to $\mathrm{Mr}$ V. C. Joshi for assistance in the fractionation of the unsaponifiable material. S.S. holds a University Grants Commission Junior Fellowship.

\section{REFERENCES}

Bernhard, K. (1947). Z. Vitam.- Horm.- u. Fermentforsch. $1,199$.

Bernhard, K. \& Schonheimer, R. (1940). J. biol. Chem. 133, 707.

Clark, A. J. \& Bloch, K. (1959a). J. biol. Chem. 234, 2578.

Clark, A. J. \& Bloch, K. (1959b). J. biol. Chem. 234, 2583.

Clark, A. J. \& Bloch, K. (1959c). J. biol. Chem. 234, 2589.

Cornforth, J. W. (1959). J. Lipid Res. 1, 3.

Fraenkel, G. \& Blewett, M. (1946). J. exp. Biol. 22, 172.

Fraenkel, G. \& Blewett, M. (1947). Biochem. J. 41, 475.

Ichikawa, M. \& Ishizaki, H. (1963). Nature, Lond., 198, 308.

Ito, T. (1960). Nature, Lond., 191, 882.

Ito, T. (1961). Bull. seric. Exp. Sta. Japan, 17, 91.

Jayaraman, J. \& Ramasarma, T. (1961). J. sci. industr. Res. 20, 69.

Kirimura, J., Saito, M. \& Kobayashi, M. (1962). Nature, Lond., 195, 729.

Kodicek, E. \& Levinson, Z. H. (1960). Nature, Lond., 188, 1023.

Levinson, Z. H. (1955). Riv. Parassit. 16, 113.

Lipke, H. \& Fraenkel, G. (1956). Annu. Rev. Entom. 1, 17. Louloudes, S. J., Kaplanis, J. N., Robbins, W. E. \& Monroe, R. E. (1961). Ann. Entom. Soc. Amer. 54, 99.

Monroe, R. E. (1960). Ann. Entom. Soc. Amer. 53, 821.

Murthy, M. R. V. (1953). Ph.D. Thesis: University of Bombay.

Robbins, W. E., Kaplanis, J. N., Louloudes, S. J. \& Monroe, R. E. (1960). Ann. Entom. Soc. Amer. 53, 128. Saito, M., Yamazaki, M. \& Kobayashi, M. (1963). Nature, Lond., 198, 1324.

Sedee, P. D. J. W. (1961). Arch. int. Physiol. Biochim. 69, 295.

Teitz, A. (1961). J. Lipid Res. 2, 182.

Viswanathan, C. V. \& Meerabai, B. (1961). J. Chromat. 6, 264.

Zebe, E. C. \& McShan, W. H. (1959). Biochim. biophys. Acta, 31, 513. 